\title{
Protein FAM131B
}

National Cancer Institute

\section{Source}

National Cancer Institute. Protein FAM131B. NCI Thesaurus. Code C106342.

Protein FAM131B (332 aa, $36 \mathrm{kDa}$ ) is encoded by the human FAM131B gene. This protein has no known function. 